\title{
ARTICLES
}

\section{EFFECTIVENESS OF AWARENESS PROGRAM ON KNOWLEDGE REGARDING ORGAN DONATION AMONG ADOLOSCENTS}

Mrs. G. Brindha Mary ${ }^{*}$ I Dr. S. S. Sharmila Jansi Rani ${ }^{* *}$

*Assistant Professor, Thasiah College of Nursing, Marthandam, Tamil Nadu, India.

**Vice Principal, Christian College of Nursing, Neyyoor, Tamil Nadu, India.

DOI: http://doi.org/10.47211/idcij.2020.v07iws02.005

\section{ABSTRACT}

Organ donor is a real hero. One organ and tissue donor has the potential to save and enhance more than 50 lives. Not only do transplant patients benefit from organ donations, but so do their family and friends. That is what makes close collaboration with the health care system and public education about donation so critical to human life. The data was collected from 60 adolescents in selected schools at Kanyakumari district by using structured knowledge questionnaire regarding organ donation. Simple random sampling technique was used to select the sample. The mean pre-test mean value was 13.61 with standard deviation of 2.04 where as in posttest mean value was 24.92 with standard deviation of 3.42. The mean difference was 11.31. It shows that there was increase in the post-test knowledge score. The Paired ' $t$ ' value was 39.32 which is higher than the table value and was significant and it shows there was effectiveness of awareness programme. The association between the knowledge with the selected demographic variables, some of the factors were having association with the selected demographic variables were significant at $P<0.001$ significance which shows that research hypothesis is partially accepted and partially rejected.

Key Words: Awareness program, Organ donation, transplantation.

\section{ABOUT AUTHORS:}

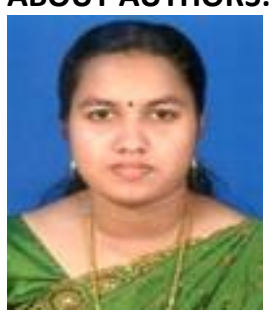

Author, G. Brindha Mary is working as an assistant professor in Thasiah College of Nursing, Marthandam, K.K. District, Tamil Nadu, India.

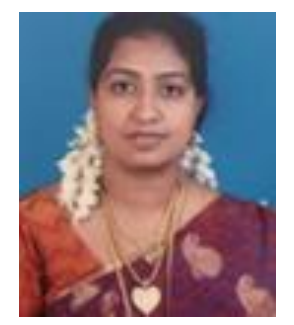

Author, Dr. S. S. Sharmila Jansi Rani is the Vice Principal and professor of Christian College of Nursing, Neyyoor, K. K. District, Tamil Nadu, India. 


\section{INTRODUCTION}

Organ donation is a major health need of the world. Organ donation is the act of a healthy person giving an organ to another person in need of a healthy organ. For some organs, the donation can be given while the healthy person is alive and in other cases, the donation is made at death. Donation may be for research or, more commonly, healthy transplantable organs and tissues may be donated to be transplanted into another person.

Common transplantation includes kidneys, heart, liver, pancreas, intestines, lungs, bones, bone marrow, skin, and corneas. Some organs and tissues can be donated by living donors, such as a kidney or part of the liver, part of the pancreas, part of the lungs or part of the intestines, but most donations occur after the donor has died.

According to the World Health Organization, only around 0.01 percent of people in India donate their organs after death. Some of the reasons behind that is lack of public awareness, religious or superstitious beliefs among people, and strict laws.

Adolescents represent the future of the society and have a direct influence on family members and friends. Adolescence is the period of rapid changes in the individual's physical, mental, moral, emotional, social and sexual aspects. Human personality develops new dimensions. It is the period to learn new things. It is also a period of anxieties and worries. It is the period of ambitions as well as of conflicts and complexities. A.T. Jersield defines, "Adolescence is that span of years during which boys and girls move from childhood to adulthood, mentally, emotionally, socially and physically".

People may not know that want to donate their organ during their living period and after their death. Educate the adolescents about the need and uses of organ donation may reduce the death rate of people who need in organ donation.

\section{STATEMENT OF THE PROBLEM}

A study to assess the effectiveness of awareness program on knowledge regarding organ donation among adolescents in selected schools, at Kanyakumari District.

\section{OBJECTIVES}

1. To assess the techniques of intravenous medication therapy among student nurses of Mata Mohan Dai Oswal college of Nursing, Ludhiana, Punjab.

2. To assess and compare the pre-test and post test score on knowledge regarding organ donation among adolescents.

3. To determine the effectiveness of awareness program on knowledge regarding organ donation among adolescents

4. To find out the association between the post test score on knowledge regarding organ donation among adolescents with selected socio demographic variables.

\section{HYPOTHEES}

$\mathrm{H}_{1}$ - There will be a significant difference between pre-test and post test score on knowledge regarding organ donation among adolescents.

$\mathrm{H}_{2}$ - There will be significant association between the post test score on knowledge regarding organ donation among adolescents with selected socio demographic variables.

\section{RESAERCH METHODOLOGY}

RESEARCH APPROACH: Quantitative evaluative approach.

RESEARCH DESIGN: Pre experimental one group pre-test post-test design.

SETTING OF THE STUDY: Selected schools at Kanyakumari district, Tamil Nadu.

POPULATION: Adolescents between 16-18 years who were studying in the selected schools of Kanyakumari district, Tamil Nadu.

SAMPLE AND SAMPLING TECHNIQUE

SAMPLE: Adolescents between the age group of 16-18 years who were studying in selected schools at Kanyakumari district, Tamil Nadu.

SAMPLE SIZE: 60 adolescents between the age group of 16-18 years who were studying in selected schools at Kanyakumari district, Tamil Nadu. 
SAMPLE TECHNIQUE: Simple random sampling technique DEVELOPMENT OF TOOL

Two tools were used in this study.

Tool 1: Socio demographic Proforma consisted on background data of the participants. It included age, gender, religion, grade, dietary pattern, hobbies, academic performance, place of living, type of family, family history of organ donation, previous knowledge about organ donation and sources of information.

Tool 2: Structured knowledge questionnaire was constructed for the adolescents in the form of multiple choice questions. It consisted of 30 items, Score of 1 was allotted for each correct answer and score of 0 was allotted for each incorrect answer. The total maximum and minimum score were 30 and 0 respectively.

\section{DATA COLLECTION PROCEDURE:}

Phase-1: After obtaining initial permission and formal approval from the school authority's pre-test was conducted to the adolescents by using knowledge questionnaire on organ donation.

Phase - 2: On the same day Awareness program was conducted by the investigator.

Phase - 3: After seven days of awareness program post test was conducted to the adolescents by using same structured knowledge questionnaire.

FINDINGS OF THE STUDY

Data pertaining to pre-test and post-test level of knowledge regarding organ donation among adolescents.

\begin{tabular}{|c|c|c|c|c|}
\hline \multirow{2}{*}{ Level of knowledge } & \multicolumn{2}{|c|}{ Pre test } & \multicolumn{2}{c|}{ Post test } \\
\cline { 2 - 5 } & Frequency & Percentage & Frequency & Percentage \\
\hline Adequate & 0 & 0 & 41 & 68.33 \\
\hline Moderately adequate & 38 & 63.3 & 19 & 31.67 \\
\hline Inadequate & 22 & 36.67 & 0 & 0.00 \\
\hline Total & 60 & 100 & 60 & 100 \\
\hline
\end{tabular}

Data pertaining to assess the effectiveness of awareness program on knowledge regarding organ donation among adolescents

$\mathrm{N}=60$

\begin{tabular}{|c|c|c|c|c|r|r|}
\hline \multicolumn{2}{|c|}{ Pre test } & \multicolumn{2}{c|}{ Post test } & $\begin{array}{c}\text { Mean } \\
\text { difference }\end{array}$ & $\begin{array}{c}\text { Paired 't' } \\
\text { test }\end{array}$ & P value \\
\cline { 1 - 3 } Mean & SD & Mean & SD & 11.31 & 39.32 & $59 \mathrm{df}$ \\
0.61 & 2.04 & 24.94 & 3.42 & & & $\begin{array}{c}0.001 \\
\text { Significant }\end{array}$ \\
\hline
\end{tabular}

Data on association between the post-test level of knowledge and selected socio demographic variables among adolescents

By using the chi-square it was found that some demographic variables like religion, dietary pattern, family history of organ donation and previous knowledge were having association with the knowledge. So, the research hypothesis was partially accepted.

\section{CONCLUSION}

Based on the findings of the study, the score on knowledge regarding organ donation has been increased. This implied that awareness program has significant effect on increasing the knowledge among the adolescents.

\section{RECOMMENDATIONS}

* The same study can be conducted on a larger population

* A similar study can be conducted in clinical settings.

* The study can be performed as comparative study in different settings

* A similar study can be conducted for different age group.

* Study can be done related to benefits of organ donation.

* There should be major initiative to spread awareness among the general public by conducting periodic mass education. 


\section{ARTICLES}

\section{REFERENCES}

1. Lewis. Text book of medical surgical sursing. $7^{\text {th }}$ edition. Elsevier publication.

2. Marilyn J. Hockenberry, David Wilson., Wong's. Essentials of Paediatric Nursing. Elsevier publications.2012. pg. No. 605

3. Dorothy R. Marlow., A Text Book of Paediatric Nursing. India: Elsevier publication. 2013.

4. Dutta. P. Paediatric Nursing. New Delhi. Jaypee Brothers Medical Publishers: 2015.

5. Joyce. M. Black., Medical Surgical Nursing. Elsevier publication. Pg No. 1005-1012.

6. Brunner. Text book of Medical Surgical Nursing. $11^{\text {th }}$ edition. Elsevier Publication. Pg. 12101215.

7. Dr. K. Lalitha. 2014. Knowledge and attitude regarding organ donation among undergraduate. Asian Journal of Nursing Education and Research. Vol. IV. 2. Pg. No. 195

8. Manonmasni. 2016. IEC package of knowledge and attitude regarding organ donation. Journal of Community Health Nursing. Nol. Pg No. 10.

9. Annadurai K. 2013. Attitude and practices about organ donation among college students. Health Science. Vol.3 pg no. 2

10. Subodh Kumar Yadav. 2015. Knowledge and attitude regarding Eye donation among under graduate nursing students. International Journal of Interdisciplinary and Multi-disciplinary Studies (IJIMS). Vol. 2. Pg No. 17-23. 